\title{
Určení rozsahu půdy nechráněné vegetací v období přívalových srážek za účelem posouzení erozního rizika
}

\section{JOSEF KRÁSA, ADAM TEJKL, JAKUB STAŠEK}

Klíčová slova: vodní eroze - GIS - dálkový průzkum Země - precizní zemědělství

\section{SOUHRN}

Článek popisuje metodu, zdrojová data i výsledky analýzy erozní ohroženosti podle nové metodiky využití dálkového průzkumu Země pro ochranu zemědělské půdy. Metoda je testována na pozemcích AGRA Řisuty, s. r. o. Pro zjištění prítomnosti vegetačního pokryvu na jednotlivých půdních blocích či jejich částech jsou využívána data $z$ družic Landsat 8 a Sentinel 2. Dále jsou použita existující data zemědělského podniku o evidenci termínů agrotechnických postupů pro tvorbu kalibračních polygonů a výpočet faktoru ochranného účinku vegetace. Družicové scény jsou získávány ze serveru Land Viewer a zpracovávány v GIS. Sloučením zpracovaných dat vznikají mapy k další analýze, a je tak získán přehled o pozemcích a jejich předpokládaném a reálném ohrožení vodní erozí.

Pozemky o celkové ploše přesahující 1500 ha byly sledovány po období tři vegetačních sezon (2015-2017). Nejrizikovější byl rok 2015, kdy se holé pưdy vyskytovaly až na 1000 ha během období července a srpna. Významným faktorem pro výskyt holých půd v období výskytu erozně účinných srážek na pozemcích AGRA Řisuty je výsev řepky ozimé.

Úskalím př́stupu je stále nízká dostupnost bezoblačných družicových scén pro období nástupu přívalových srážek a rychlého rozvoje vegetačního pokryvu v rizikovém období červen-srpen. Další nejistotu do analýzy vnáší identifikace půdy nezakryté vegetací v období vysoké zralosti pěstovaných plodin, $v$ tomto období je nutné konfrontovat výsledky s datem načasování sklizní jednotlivých půdních bloků.

Metoda se jeví jako vhodná pro využití jednotlivými zemědělskými podniky, přičemž nejistota při určování půdního pokryvu je dále redukována snadnou dostupností kalibračních dat z terénu a jednoduchým prístupem ke sklizňovým datům. Vypuštěním družice Sentinel 2 B v roce 2017 se také zlepšila dostupnost dostatečného množství dat v ucelených časových řadách.

\section{ÚVOD}

V současné době je trendem optimalizace výnosů v zemědělství pomocí metod precizního zemědělství a sledování prostorového rozložení výnosů $v$ rámci půdních bloků. Na základě posouzení dlouhodobých růstových charakteristik je možno cíleně aplikovat hnojiva, ale též ochranné postřiky, a to jak z dưvodu ekonomických úspor, tak za účelem dalšího zvyšování výnosů a zisku. Zároveň jsou však v České republice zemědělské pozemky vystavovány riziku degradace půdy vlivem vodní eroze, která se kromě známých negativních efektů pro vodu a půdu podílí i na prípadném snižování výnosů (poškození osiva, vzrostlých plodin, snížení úrodnosti půdy apod.). Prostorově správné posouzení erozního rizika je tedy potřebné jednak pro ochranu půdy, ale rovněž pro zlepšení zemědělské produkce, což je v souladu s cíli nejen precizního zemědělství.

Metodika využití volně dostupných družicových dat pro sledování prostorové distribuce růstu zemědělských plodin byla v ČR publikována Lukasem [1]. Od roku 2015 jsou pak pro doplnění časové řady a omezení problémů s oblačností v družicových scénách k dispozici kromě dat z programu Landsat (družice Landsat 5, Landsat 7 a Landsat 8) rovněž data z programu Copernicus (družice Sentinel 2). Ta mohou výrazně napomoci ke zkvalitnění analýz vývoje vegetačního růstu pomocí vegetačních indexů, zejména nejčastěji využívaného normalizovaného indexu NDVI. Družice Sentinel 2 A odstartovala v červnu 2015, družice Sentinel 2 B v březnu 2017. Společně tak poskytují časové rozlišení přibližně tři dny pro území ČR. Data Sentinelu 2 jsou získávána v celkem 13 spektrálních kanálech o rưzných vlnových délkách [2].

Běžným způsobem hodnocení erozního rizika $\vee$ ČR, používaným jak při vymezení rizikových ploch $\vee$ rámci kontroly podmíněnosti zemědělských dotací, tak při návrzích opatření např. v pozemkových úpravách, je posouzení pomocí Univerzální rovnice ztráty půdy - USLE [3-5]. Je obecnou shodou, že dlouhodobě rizikové lokality lze při dostatečně podrobných vstupních datech $\checkmark$ rámci výpočtu $v$ libovolném geografickém informačním systému pomocí metody USLE v její prostorově distribuované podobě (USLE2D, USLE3D) identifikovat dostatečně přesně [6]. Nicméně reálné erozní riziko závisí kromě výskytu přivalové srážky také na vegetačním pokryvu. Ten Ize dlouhodobě popsat pomocí vyhodnocení skutečných osevních postupů [7], nicméně v konkrétním roce jej Ize na rozsáhlých plochách nejrychleji odhadnout s využitím výše citovaných družicových dat.

Zde se nabízí využití družicových scén nejen k určení pokryvnosti a ochranného účinku vegetace, ale rovněž k vymezení zcela odkrytých půd a vývoje poklesu zastoupení holé půdy na povodích i na konkrétních pozemcích během vegetační sezony [8]. Znalosti o zastoupení holé pưdy v erozně rizikových periodách roku pak pomáhají jednak zacílit protierozní ochranu, ale rovněž lépe vytipovat lokality, kde je třeba po výskytu přivalových srážek monitoringem ověrit, zda ke skutečnému eroznímu poškození dochází. Výzkumný ústav meliorací a ochrany půdy inicioval dlouhodobý celostátní monitoring eroze zemědělské půdy, který je významným verifikačním nástrojem pro výše uvedené hodnocení metodou USLE, ale také pro řadu srážkoodtokových modelů transportu splavenin do povrchových vod a infrastruktury. Samotný monitoring je vlastním šetřením i na podněty od veřejnosti prováděn pracovníky Státního pozemkového úřadu, který databázi zaštituje, a pro veřejnost je dostupný na 


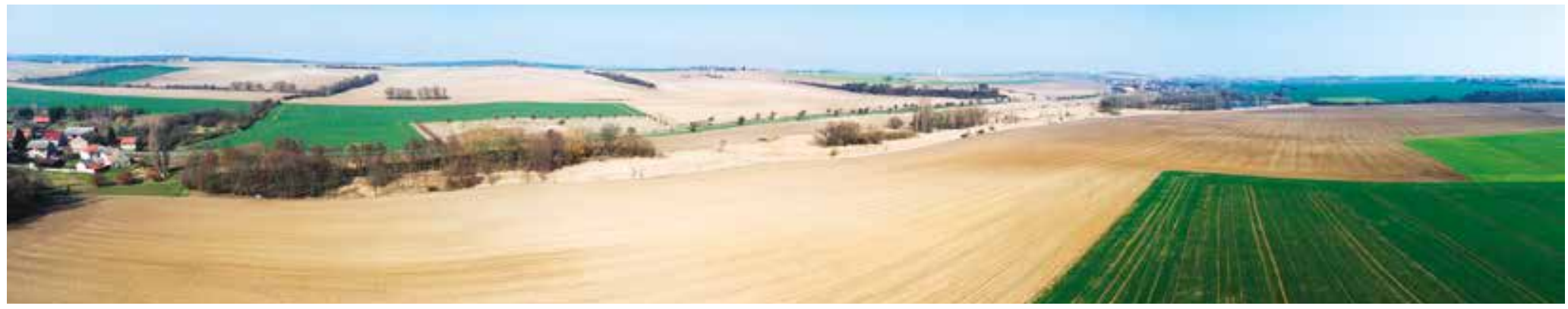

Obr. 1. Panoramatický UAV snímek řešené lokality v okolí Řisut s ukázkou rozsahu holých půd (17. 3. 2016)

Fig. 1. Panoramic UAV image of the area around Řisuty with a demonstration of the extent of bare soil (17. 3. 2016)

adrese https://me.vumop.cz/. Distanční metody monitoringu (dálkový průzkum Země a vyhodnocení ortofotomap a snímků z bezpilotních prostředků) byly rozvíjeny během projektu Ministerstva zemědělství QJ1330118 Monitoring erozního poškození půd a projevů eroze pomocí metod DPZ řešeného v letech 2013-2016 a jeho výsledky byly publikovány v certifikované metodice [8]. S cílem lépe využít metody dálkového průzkumu pro predikci lokalit, kde je vhodné provést operativní pozemní průzkum, byl zahájen návazný projekt QK1720289 Vývoj automatizovaného nástroje pro optimalizaci monitoringu eroze zemědělské půdy pomocí distančních metod. Propojení hodnocení erozního rizika a postupů precizního zemědělství si pak klade za jeden z cílů projekt EIP Implementace nových a inovovaných technologií precizního zemědělství do pěstebních systémů, registrační číslo 16/003/1611a/120/000095. Ten je řešen ve spolupráci se společností AGRA Řisuty, s. r. o., na jejíchž pozemcích byly rovněž testovány prezentované postupy.

\section{METODIKA}

\section{Lokalita}

Zájmové pozemky se nacházejí severovýchodně od Prahy, nedaleko okresního města Slaný. Pozemky se rozkládají na katastrálních územích celkem 16 obcí, a to Byseň, Drnek, Hradečno, Jedomělice, Ledce u Kladna, Libovice u Slaného, Lodenice, Lotouš, Malíkovice, Mšec, Pozdeň, Přelíc, Řisuty u Slaného, Smečno, Studeněves a Svinařov u Kladna. Jedná se celkem o 129 pozemků s celkovou rozlohou 1731 ha. Využití pozemků je predevším jako standardní orná půda, v menší míre travní porost na orné půdě či trvalý travní porost (obr. 1).

Morfologie oblasti má charakter ploché pahorkatiny s výškovou členitostí 30 až 75 metrů. Nadmořská výška řešených pozemků je v rozmezí 280 až $430 \mathrm{~m}$ n. m. Průměrné sklony na řešených pozemcích se pohybují v rozmezí 2,7-5,9․ Z klimatického hlediska je oblast mírně teplá a suchá s mírnou zimou. Průměrná roční teplota se pohybuje okolo $8^{\circ} \mathrm{C}$. Roční srážkový úhrn z hlediska ČR je podprůměrný a pohybuje se mezi 450 až $550 \mathrm{~mm}$.

Farma AGRA Řisuty dlouhodobě aplikuje mělké zpracování pưdy a šetrné technologie, během monitoringu erozní ohroženosti prováděného na pozemcích farmy proto nebylo zachyceno výrazné erozní poškození.

\section{Vstupní data}

Pro stahování a základní zpracování družicových scén je možné v současné době využít řadu internetových portálů. Pro data z programu Landsat jsou to Earth Explorer [9], GloVis, LandsatLook, ESA Landsat 8 Portal (pouze pro Landsat 8), Global Land Cover Facility [10] a jiné. Zajímavým rozhraním je portál
Global Land Cover Facility, kde jsou ke stažení jak vybrané scény z některých družic (Landsat, Terra, Ikonos), tak odvozené produkty (např. krajinný pokryv, vegetační index, maska vodních ploch nebo albedo). Pro prístup k datům z družic Sentinel všem uživatelům slouží portál ESA Sentinel Scientific Data Hub, pro stažení scén stačí jednoduchá registrace. Prímé analýzy nad daty Ize provádět efektivně v komerčním prostředí nazvaném jednoduše Sentinel Hub, provozovaném firmou Sinergise [11]. Zajímavým zdrojem družicových scén obou systémů pak může být server LandViewer [12], provozovaný firmou EOS. Ten byl využit i pro zajištění dat na lokalitě Řisuty.

Periodicita scén z družice Landsat 8 je 16 dní. Za vegetační sezonu osmi měsíců (období březen-říjen) jich tedy teoreticky může být k dispozici až 15. Periodicita družice Sentinel $2 \mathrm{~A}$ je pro řešené území méně než 7 dní, nicméně data začala být pořizována od července 2015. Společně s družicí Sentinel 2 B je periodicita dat pro řešené území v rozmezí 3-4 dny, nicméně tato data začala být pořizována $v$ breznu 2017. $\vee$ současnosti proto čistě teoreticky může být k dispozici pro období osmi měsíců březen-ř́ijen až 80 rưzných satelitních scén z uvedených systémů. Nicméně dostupnost dat značně limituje oblačnost nad hledaným územím a reálně dostupné počty scén jsou podstatně nižší. Data družic Sentinel 2 jsou poskytována v různých úrovních předzpracování, surová data z výše uvedenou frekvencí nejsou prímo prakticky využitelná. Pro praktické využití je třeba čerpat ze scén převedených do produktu úrovně L1C, které jsou ošetřeny atmosférickou korekcí a ortorektifikovány [2]. Dostupný počet skutečně využitelných scén je tak proti teoretickému počtu vypočtenému z periody obletu již značně omezen.

V databázi satelitních scén na serveru LandViewer byla vybrána zájmová lokalita a pro ni byly vybrány scény pořízené družicemi Landsat 8, Sentinel $2 \mathrm{~A}$ a Sentinel 2 B. Při podmínce oblačnosti nižší než 20 \% bylo pro vegetační sezonu (období březen-řijen) roku 2015 nalezeno 17 scén, pro vegetační sezonu roku 2016 bylo nalezeno 23 scén a pro vegetační sezonu roku 2017 potom 18 scén (obr. 2). Z těchto souborů pak byly vybírány scény, na kterých je celá zájmová oblast nezastíněna oblačností. Počet vhodných scén tak byl dále redukován zhruba na čtvrtinu.

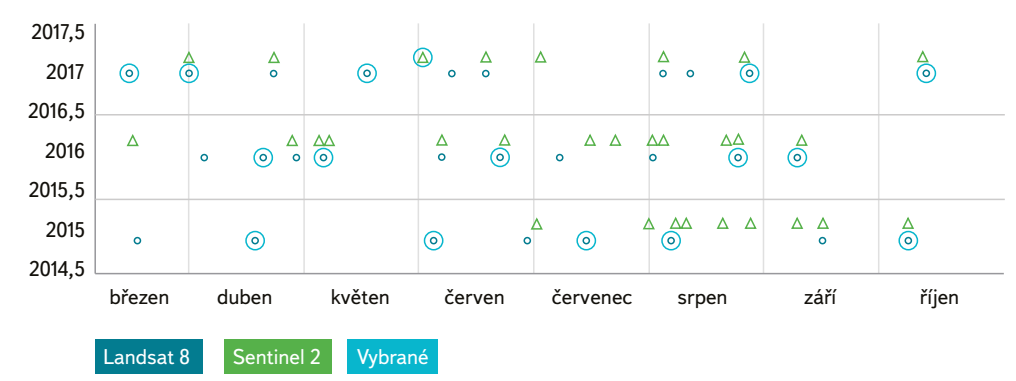

Obr. 2. Dostupné bezoblačné družicové scény zájmového území v letech 2015-2017 Fig. 2. Available cloudless satellite scenes of the target area for the years 2015-2017 
Celkem bylo analyzováno 16 scén, pro každý rok jich bylo nejméně pět (tabulka 1). Data pořízení vybraných scén byla volena tak, aby co nejvíce postihovala vegetační období a tu část roku, kdy je nejvyšší riziko výskytu srážkových událostí způsobujících erozní poškození.

Použity byly scény z družice Landsat 8 s prostorovým rozlišením $30 \mathrm{~m}$. Pouze družicová scéna ze dne 27. 8. 2016 je pořizena družicí Sentinel 2s prostorovým rozlišením $10 \mathrm{~m}$. Vždy byly staženy rastry kompozice RGB, NI a NDVI, tedy viditelná a blízká infračervená pásma spektra.

Pro hodnocené pozemky byla dále firmou AGRA Řisuty poskytnuta reálná data o plodinách, datech setí a sklizní a výnosech v letech 2015, 2016 a 2017. Data byla z hlediska precizního zemědělství doplněna o izolinie průměrných normalizovaných výnosů na jednotlivých pozemcích. Výsledný normalizovaný výnos vyjadřuje, o kolik procent byl v daném bodě výnos vyšší nebo nižší než průměr celého pozemku $v$ daném roce [1]. Tento relativní výnosový potenciál (či produkční zóny) vychází z hodnocení variability porostu z družicových multispektrálních snímků za posledních 8 let. Procentuální hodnota je stanovena pro každý pozemek zvlášt a ukazuje na slabá či silná místa na pozemcích. Nelze však porovnávat pozemky mezi sebou, už jen z principu rozdílných plodin. Pro Řisuty byly zóny vypočteny s rozlišením $5 \mathrm{~m}$. Pro území celé České republiky jsou v hrubé podobě produkční zóny dostupné na adrese http://foodie.lesprojekt.cz.

Pro hodnocení erozní ohroženosti byly potom využity následující údaje. Výškopis, který vstupuje do použitého modelu Atlas EROZE jako mračno bodů z digitálního modelu reliéfu 5. generace [13]. Faktor erozního účinku deště, který je uvažován průměrnou dlouhodobou roční hodnotou $40 \mathrm{MJ} \cdot \mathrm{ha}^{-1} \cdot \mathrm{cm} \cdot \mathrm{h}^{-1}$ [14]. Faktor erodovatelnosti půdy, odvozený z volně dostupných vektorových map bonitovaných půdně ekologických jednotek [15]. Faktor ochranného účinku vegetace, který je odvozen z výše uvedených údajů o osevních postupech a termínech agrotechnických operací. Technická protierozní opatření nejsou na pozemcích farmy AGRA Řisuty aplikována.

\section{Identifikace půdy nepokryté vegetací}

Nepokryté půdy byly na scénách identifikovány na trénovacích množinách, tedy vybraných půdních blocích. Na jarních scénách to byly jednak pozemky čerstvě po zasetí, evidované podle termínu setí jednotlivých plodin, dále pozemky prokazatelně bez vegetace při RGB zobrazení v přirozených barvách. Na ostatních scénách pak pozemky s analogickým príznakem v RGB zobrazení a rovněž s hodnotami indexu NDVI ukazujícími na neexistenci vegetace na daných pozemcích. Po vytvoření trénovacích množin byly následně holé půdy na každé scéně vyhodnoceny na všech LPIS blocích pomocí ŕizené klasifikace klasifikátorem Maximum Likelihood v prostředí ArcGIS. Celá analýza probíhala pouze na zemědělské půdě, ostatní kategorie využití byly ponechány jako nehodnocená data. Dalším krokem bylo určení procenta výskytu holé půdy v každém období na každém pozemku nástroji prostorové statistiky. Data byla z map prevedena do atributů databáze pozemků a do grafického vyjádření. Data o holé půdě dostupná z družicových scén byla doplněna o data známá z termínů agrotechnických prací (termíny setí), ve kterých jsou pozemky označeny jako zcela holé. Následně byly holé části pozemků ve vegetačním období konfrontovány s rizikem výskytu erozně účinných srážek a s prostorově distribuovanou vrstvou potenciální erozní ohroženosti.

Prostorově bylo v GIS mapovou algebrou vypočteno riziko výskytu holých půd během vegetační sezony s ohledem na riziko výskytu erozně účinných srážek. Výpočet vycházel z dlouhodobého prưměrného erozního účinku srážek (R-faktoru) v jednotlivých měsících v procentech za období duben-záŕí [14]. Toto období představuje 100 \% celkového erozního účinku srážek. Distribuce erozně účinných srážek během roku pro období poslední dekády byla nově určena ČHMÚ [16]. Princip výpočtu byl následující.

Pro termín každé analyzované družicové scény je váženým průměrem určeno procento erozního účinku srážek reprezentovaného období. Procenta z tabulky (tabulka 2) jsou takto lineární interpolací rozdělena mezi data, ve kterých byl určen výskyt holých půd $v$ každé sezoně. Pixelům holé půdy $z$ dané scény je prriřazena tato hodnota procenta R-faktoru. Holá půda identifikovaná na dané družicové scéně má tedy váhu odpovídající období reprezentovanému datem pořízení scény. Tato procenta získaná ze všech analyzovaných scén v daném bodě pozemku byla vždy pro danou sezonu sečtena. Pokud by se tedy na dané části pozemku vyskytovala holá půda po celé sledované období konkrétního roku, získala by ve výsledné mapě hodnotu právě $100 \%$, tedy by byla uvažována jako zcela nechráněná proti erozi v daném roce.

Tabulka2. Dlouhodobásezonnídistribuce erozniho účinku srážek po měsicich v procentech Table 2. Long-term seasonal distribution of rainfall erosivity by month in percent

\begin{tabular}{llllll} 
Duben & Květen & Červen & Červenec & Srpen & Září \\
\hline $4,0 \%$ & $15,9 \%$ & $27,7 \%$ & $29,2 \%$ & $18,7 \%$ & $4,7 \%$
\end{tabular}

Následně bylo ještě vypočteno průměrné dlouhodobé riziko výskytu holé půdy jako průměr ze sledovaných let.

\section{VÝPOČET EROZNÍ OHROŽENOSTI}

Erozní ohroženost byla počitána v prostředí modelu Atlas EROZE. Atlas pracuje s digitálním modelem terénu jako s prostorovou plochou, která kopíruje zaměřený nebo projektovaný terén. Vzniká na základě 3D bodů, čar a ploch, kterými prochází. Výpočet mezi zadanými body je upraven pro modelování hladkého terénu. Formát vstupních dat, výstupních modelů a výstupních protokolů je v souladu s platnými metodikami používanými při pozemkových úpravách $\checkmark$ České republice. Metodou výpočtu je proto plošně distribuovaná (2D) verze Univerzální rovnice ztráty půdy (1) (USLE) ve tvaru:

Tabulka 1. Seznam analyzovaných scén, ve kterých se nevyskytovala oblačnost nad pozemky AGRA Řisuty

Table 1. List of analyzed scenes with detected no cloud cover over target area

\begin{tabular}{|c|c|c|c|c|c|c|c|c|}
\hline & Březen & Duben & Květen & Červen & Červenec & Srpen & Září & Říjen \\
\hline 2015 & & 19.4. & & 6.6 & 17. 7. & 9.8. & & 12. 10. \\
\hline 2016 & & 21.4. & 7. 5. & 24.6 & & 27. 8. & 12. 9. & \\
\hline 2017 & 16. 3. & 1. 4. & 19. 5. & 3. 6. & & 30.8 & & 17. 10. \\
\hline
\end{tabular}




$$
G=R \times K \times L \times S \times C \times P
$$

kde G je průměrná dlouhodobá ztráta půdy [t.ha-1.'rok-1],

$\mathrm{R} \quad$ faktor erozní účinnosti deště $\left[\mathrm{MJ} \cdot \mathrm{ha} \mathrm{a}^{-1} \cdot \mathrm{cm} \cdot \mathrm{h}^{-1}\right]$,

K faktor erodovatelnosti půdy [t.h.MJ'-1. $\mathrm{Cm}^{-1}$,

L faktor délky svahu (-),

S faktor sklonu svahu (-),

C faktor ochranného vlivu vegetačního krytu (-),

P faktor účinnosti protierozních opatření (neuvažován).

Výsledný vztah pro LS faktor je dán kombinací rovnic podle Mitášové [17], Desmeta a Goverse [18] a Nearinga [19]. Plocha dílčích povodí je počítána pomocí algoritmu identifikace odtokových linií prímo na modelech typu TIN. Výstupem je rastr LS faktoru, jehož rozlišení je určeno uživatelem $v$ nastavení programu. Odtokové linie jsou vytvářeny spouštěním „kapek“ na TIN model v hustotě, která je dána nastaveným rozlišením. $V$ tomto výpočtu bylo zvoleno rozlišení $5 \mathrm{~m}$. Ostatní faktory USLE převádí model Atlas EROZE na základě uživatelských vstupů na plošně distribuované rastrové modely s rozlišením výstupního LS faktoru.

Faktor ochranného vlivu vegetace byl uvažován ve dvou variantách. Jednak jako skutečná hodnota faktoru C na každém pozemku, vycházející z reálných osevních postupů za období 2015-2017 standardní metodou [14], jednak jako reprezentativní hodnota identická pro všechny pozemky orné půdy, za účelem výpočtu relativní erozní ohroženosti na všech pozemcích, nezávislé na konkrétní skladbě plodin za řešené tríleté období.

\section{VÝSLEDKY}

\section{Výskyt půdy nezakryté vegetací}

Mapy výskytu holých půd během vegetační sezony s ohledem na riziko výskytu erozně účinných srážek byly vytvořeny v rozlišení 30 m, odpovídajícímu původním družicovým scénám. Mapy ukazují na rizikové partie pozemkư v každé sledované sezoně od dubna do května v letech 2015-2017 (obr. 3).

Z prezentovaných map je zřejmé, že v rámci zkoumaného tříletého období je variabilita holých půd v letním období na pozemcích velmi vysoká, v závislosti na osevních postupech. Zejména závisí na tom, které pozemky jsou vybrány pro setí ozimé řepky, jež probíhá ještě v době vysokého rizika erozních srážek, v průběhu srpna, v závislosti na klimatu daného roku. Rovněž celková délka období s holou půdou na daném pozemku se obvykle v každém roce liší, v letech 2015 a 2016 byla na řadě pozemků mnohem delší než v roce 2017. Na mnoha pozemcích se $v$ roce 2015 (kdy byla situace nejhorší) vyskytovalo vysoké procento holé půdy rovněž vlivem extrémního sucha, a tedy omezeného růstu pěstovaných plodin. Kumulativní mapa výskytu holých půd v létě za celé třileté období vlivem výše uvedené časové a prostorové variability již proto neukazuje na tak významné rozdíly a hodnoty dosahují maximálně 50 \% (obr. 4).

Nejrizikovější pozemky (severně od Studeněvsi, okolí Pozdeni) tedy byly podle analýzy družicových dat vystaveny působení až 50 \% erozně účinných srážek za celé tríleté období, aniž by byly jakkoli chráněny vegetací. V souhrnu byly pozemky AGRA Řisuty za období 2015-2017 vystavené prưměrně 20 \% erozního účinku srážek, aniž by byly chráněny vegetací. V roce 2015 to bylo $35 \%$, v roce 2016 pak $21 \%$ a v roce 2017 pouze $6 \%$. Z tohoto trendu je žrejmé, že bez ohledu na běžné postupy výpočtu faktoru ochranného účinku vegetace (C - faktor) Ize na základě analýzy družicových scén určit podstatně vyšší riziko erozního ohrožení řady pozemků v suchém roce 2015 než v roce 2017. Přitom AGRA Řisuty nepěstuje širokořádkové plodiny s pozdním vegetačním nástupem (kukuřice, brambory). Při jejich zahrnutí do osevních postupů by hodnoty rizikového výskytu holých půd byly ještě vyšší.

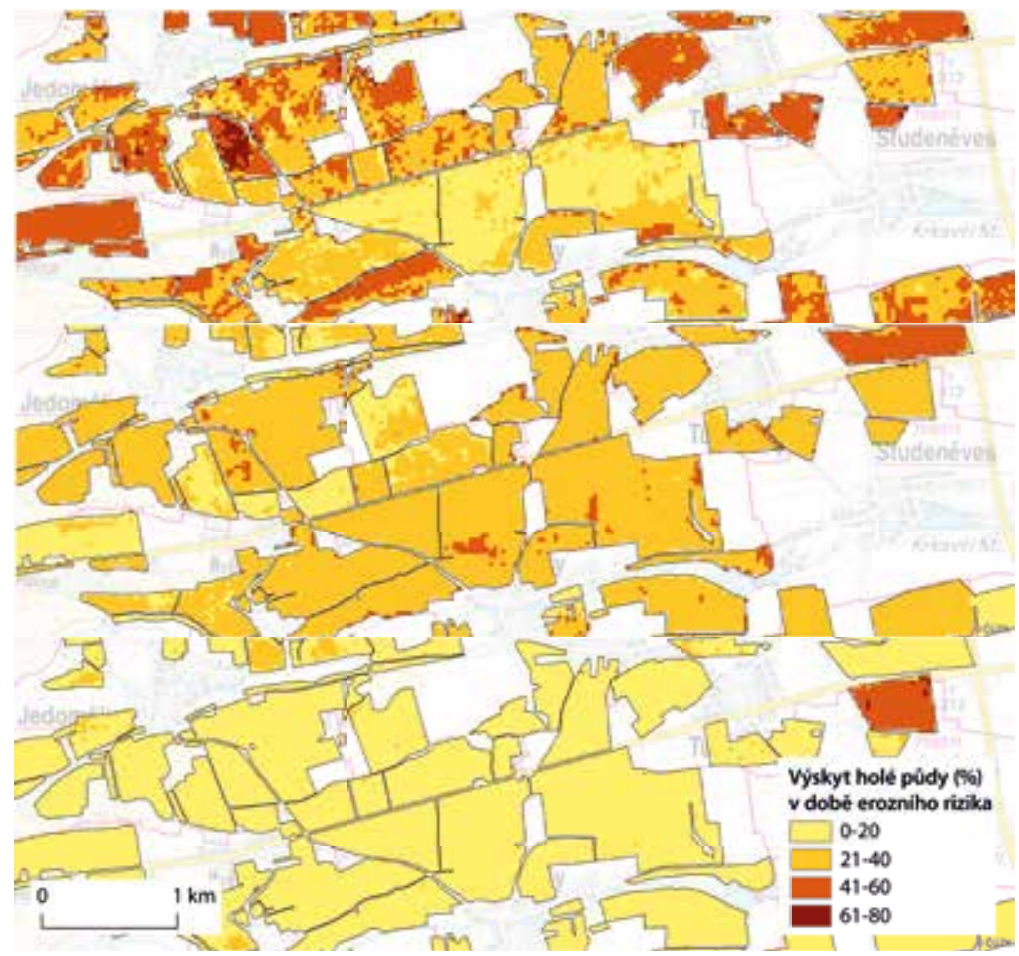

Obr. 3. Ukázka porovnání změny prostorové distribuce holé půdy na pozemcích v letech 2015-2017 se zohledněním rizika výskytu erozních srážek v každém roce podle tabulky 2

Fig. 3. Comparison of the changes of spatial distribution of bare soil in the years 2015-2017, taking into account the risk of erosion of rainfall according to the table 2

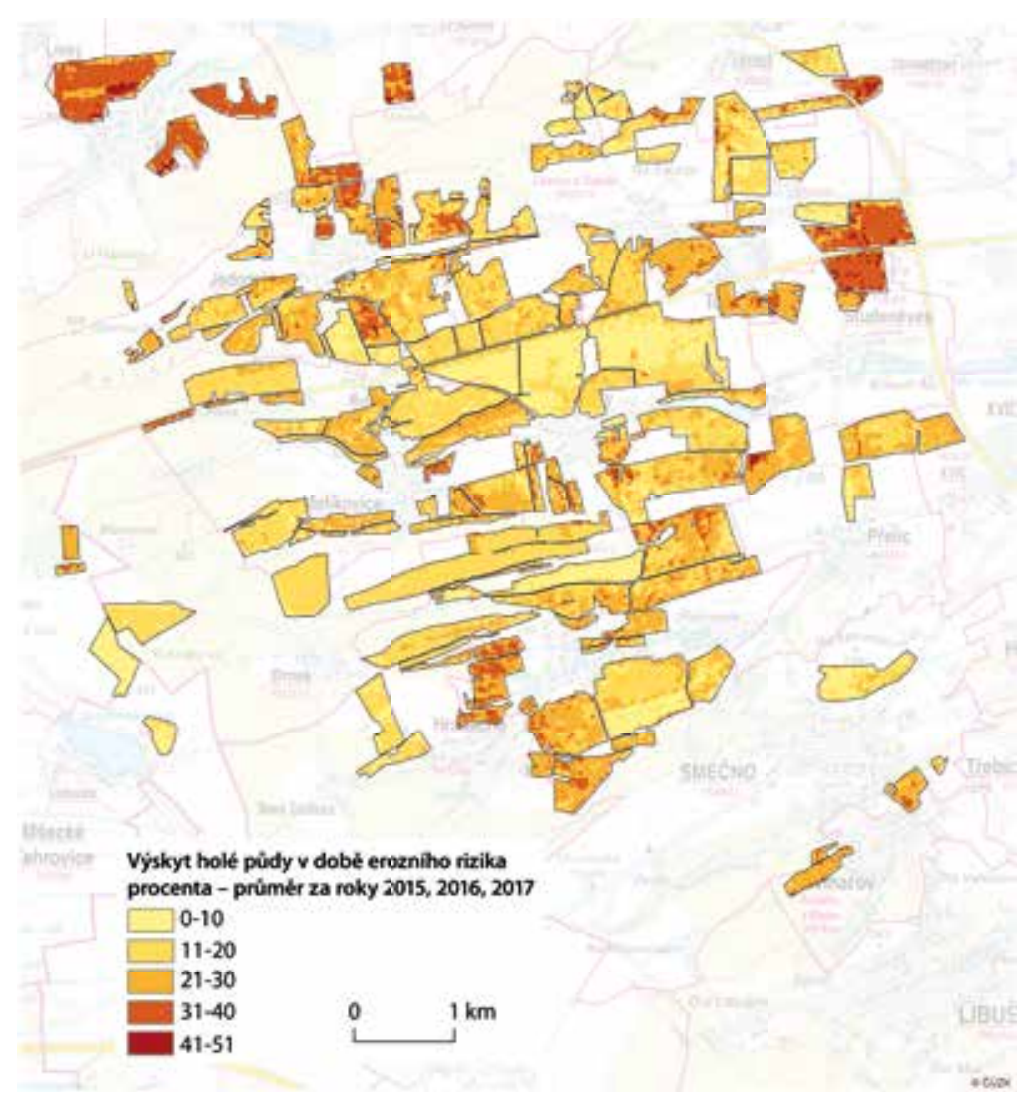

Obr. 4. Kombinovaná mapa výskytu holých půd v rizikovém období za roky 2015-2017 Fig. 4. A combined map of the occurrence of the bare soil at risk period for the years 2015-2017 


\section{Průběh zastoupení půdy bez vegetace}

Průběhy procentního rozsahu holé půdy byly sledovány individuálně pro každý jednotlivý pozemek a nejprve byly sestaveny souhrnné grafy jednotlivých plodin se zachováním informace o konkrétních pozemcích. Zde je uveden príklad pro ječmen jarní v sezoně 2015 (obr. 5) s vyznačením základních termínů změn.

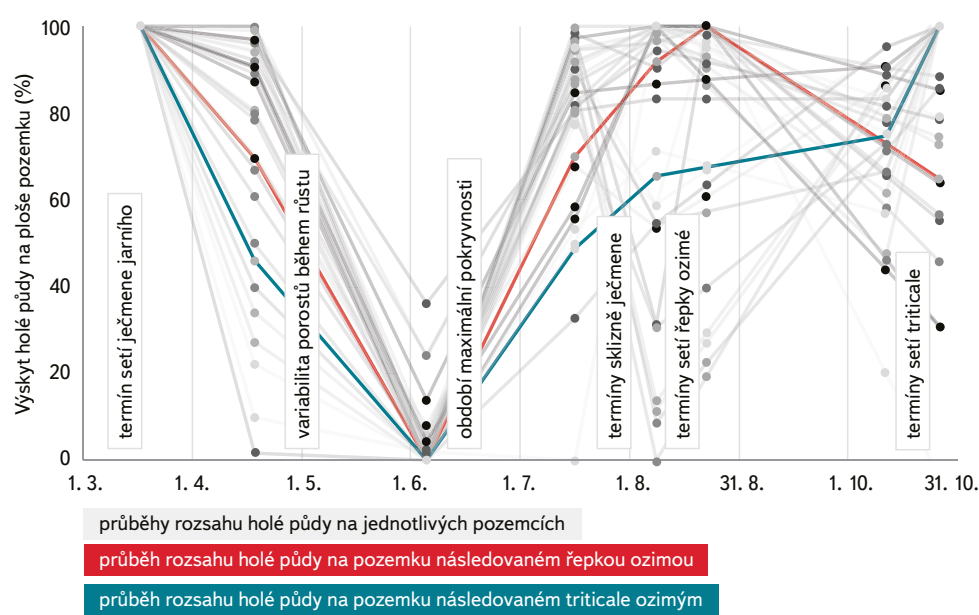

Obr. 5. Variabilita průběhu zastoupení holé půdy na pozemcích ječmene jarního v roce 2015 Fig. 5. The variability of the bare soil extent on the land of spring barley in 2015

Z obrázku je jasně patrná výrazná variabilita průběhu růstu a nerovnoměrnosti porostů v daném suchém roce. I v období maximálního vzrůstu v průběhu června a července se na některých pozemcích vyskytla holá půda. V závislosti na termínu dalšího setí jsou pak pozemky zcela holé v období srpna, pokud následuje osetí řepkou ozimou, nebo až koncem řijna, pokud je na nich ponecháno strniště a následně je zde seto triticale ozimé.

Agregací výsledků zastoupení půdy bez vegetace pro jednotlivé plodiny byl získán průběh zastoupení holé půdy pro sumu všech pozemků (obr. 6-8). Tyto grafy opět ukazuji předpokládaný pokles zastoupení holé půdy uprostřed vegetační sezony. Pro porovnání jsou $v$ grafech vyznačeny rovněž procentní významy jednotlivých měsíců z hlediska dlouhodobého erozního účinku srážek (tabulka 2). Barvy pro plodiny jsou zachovány pro všechny tři sledované roky, plodiny (pásy grafu) jsou nicméně seřazeny podle rozsahu holé půdy na konci sledovaného období. Z průběhů je jasně viditelné, jak se liší jednotlivé plodiny a jednotlivé roky. V souladu s mapovými výstupy prezentovanými výše platí, že nejvyšší rozsah holé půdy během kritického období prívalových srážek byl $v$ roce 2015. $\vee$ tomto roce dosahovala výměra holé půdy během července a srpna až 60 a 70 \% celkové plochy všech pozemků (to odpovídá až 1000 ha půdy). Nejvíce se na tomto rozsahu podílely plochy pšenice ozimé, ječmene jarního a řepky ozimé, jistý podíl má však samozřejmě také výběr plodiny pro následující sezonu a termín návazného setí. Navazující plodinou byla $v$ roce 2015 často právě řepka ozimá (obr. 5). U řepky pěstované v sezoně 2015 docházi k nárůstu rozsahu holé půdy na přelomu června a července také z důvodu rychlého zrání a časné sklizně (a případné návazné kultivace pozemků).

$\checkmark$ roce 2016 je na pozemcích během května a června jen minimum holé půdy. Rychlý nárůst plochy holé půdy v srpnu je pak opět způsoben výsevem ozimé řepky. Nejvíce se na plochách holé půdy v tomto roce podílí porosty pšenice ozimé, hrachu setého, triticale a ječmene jarního. Rok 2017 je pak z tohoto pohledu nejpríznivější. Rozsah holé půdy na pozemcích je během rizikové části vegetační sezony minimální, v srpnu dosahuje 20 \% (cca 300 ha)

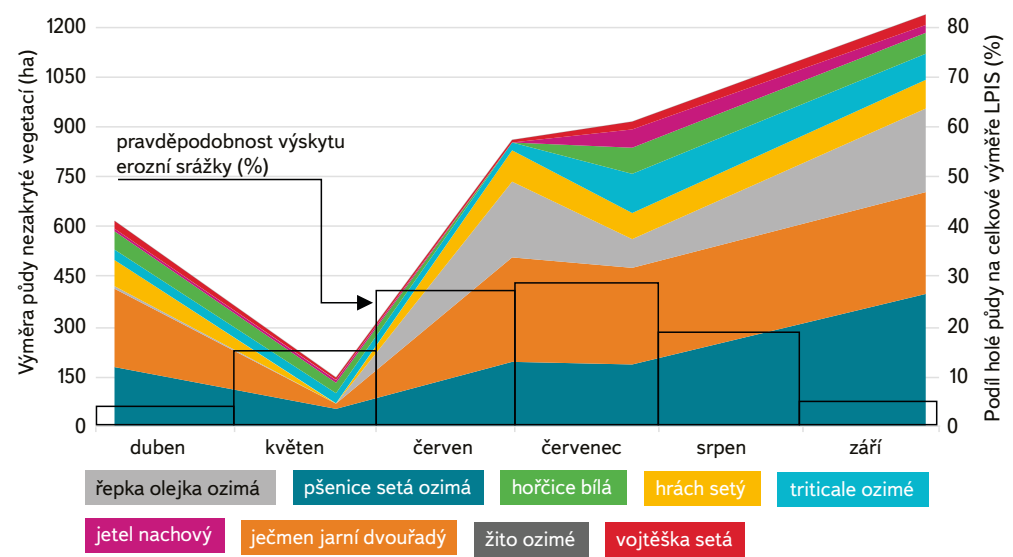

Obr. 6. Celková a procentní výměra holé půdy pro jednotlivé plodiny v roce 2015

Fig. 6. The total and percentage extent of bare soil for different crops over entire target area in the year 2015

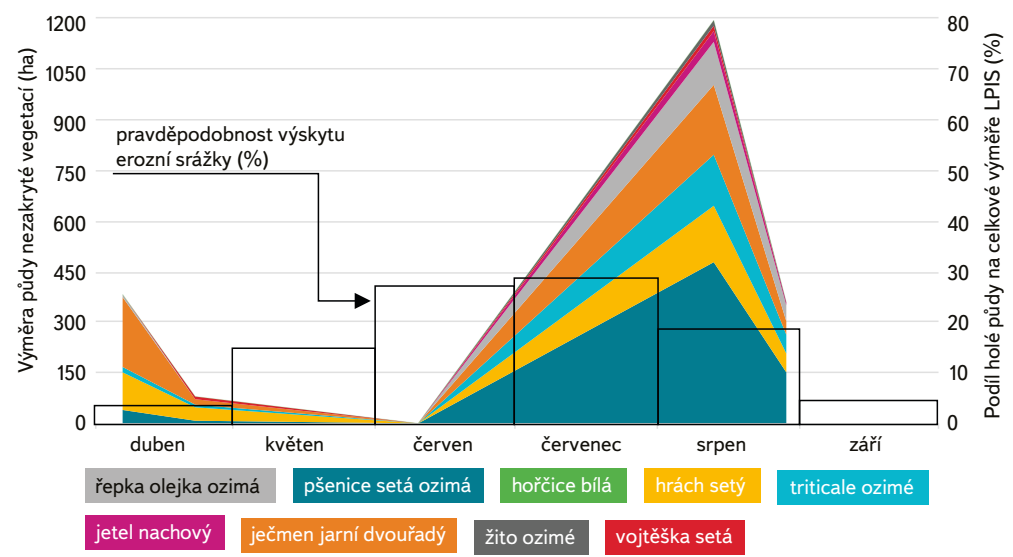

Obr. 7. Celková a procentní výměra holé půdy pro jednotlivé plodiny v roce 2016 Fig. 7. The total and percentage extent of bare soil for different crops over entire target area in the year 2016

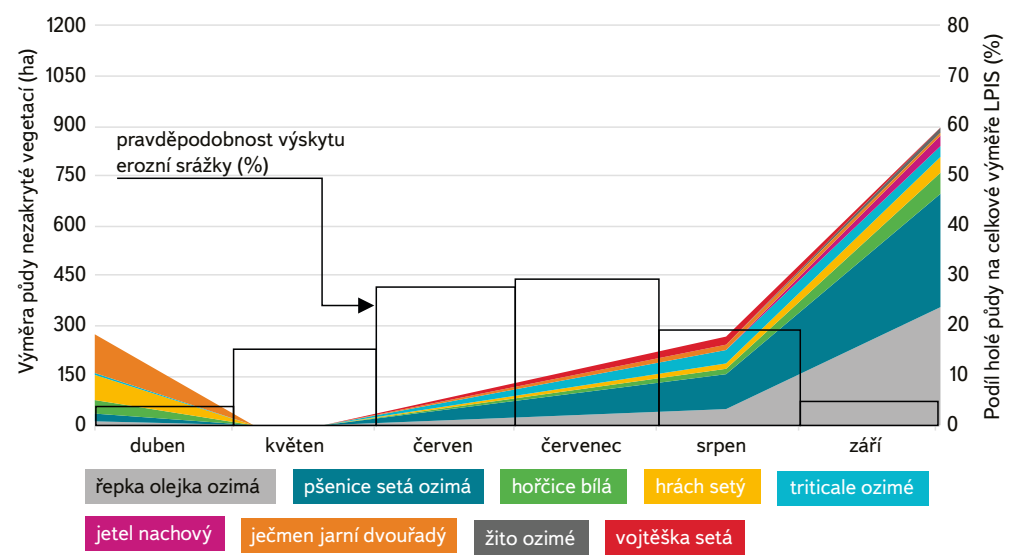

Obr. 8. Celková a procentní výměra holé půdy pro jednotlivé plodiny v roce 2017 Fig. 8. The total and percentage extent of bare soil for different crops over entire target area in the year 2017 


\section{Dlouhodobý průměrný erozní smyv}

Výsledkem výpočtu jsou mapy erozního rizika ve formě rastrových vrstev GIS. Výstupní délka hrany pixelu byla zvolena 5 m, což je běžný standard odpovídající kvalitě vstupních podkladů. Výsledky této analýzy mohou odhalit problémová místa na zemědělských pozemcích. Jedná se především o místa, kde při srážkových událostech hrozí vznik povrchového odtoku a pưdního smyvu. Na těchto místech může docházet k poškozování vzcházející vegetace, prípadně na niže ležících místech k redepozici materiálu.

Z erozních map jsme se pokusili vyčíst spojitost mezi výskytem půdy bez vegetace a hodnotou erozního rizika. Na erozních mapách z let 2015 a 2016 některé rizikové oblasti odpovídaly holým půdám již v období vegetačního růstu. Pro rok 2017 se oblasti s výskytem půdy bez vegetace a s vyšší hodnotou erozního smyvu míjely. Statisticky byla vazba mezi erozně rizikovými pozemky a výskytem holé půdy v letním období za roky 2015-2017 nevýznamná. Pro takové porovnání by však bylo třeba podstatně delší sledované období.

\section{ZÁVĚR}

Data o pozemcích a jejich částech bez vegetačního pokryvu v kombinaci se srážkovými průběhy erozně rizikových deštư jsou vstupem do procesních modelů určujících hodnoty smyvu a transportu splavenin. Zemědělské podniky informaci o termínech vlastních agrotechnických operací v aktuálním čase samozřejmě mají a evidují, ale jejich určování pro širší regiony je obtížné, vzhledem k nutnosti získávat je zpětným šetřením u jednotlivých podniků. Informace o vývoji rozsahu holých půd během roku je pak možno efektivně získat pomocí dat dálkového průzkumu Zemè.

Výsledky provedené analýzy mohou kromě potvrzení výskytu holých půd těsně po termínu setí a určení rychlosti zapojení porostu setých plodin odhalit také problémová místa na zemědělských pozemcích. Jedná se především o místa, kde rostliny špatně vzchází. Na těchto místech již mohlo dojít k destrukci úrodné svrchní vrstvy půdy, místa mohou být zamokřená, či zde došlo k redepozici erozního splachu. Identifikací těchto míst lze učinit první krok k nápravě a opět začít pole plnohodnotně užívat. Tímto Ize zvýšit hektarové výnosy plodin, prípadně upravit dělení půdních bloků. Ideálním postupem je sestavit z družicových scén dlouhodobé časové řady v odpovídajících si vegetačních obdobích. Pro komplexní popis situace na pozemcích je vhodné výsledky vyhodnocení dat dálkového průzkumu kombinovat s daty o konkrétních plodinách a datech výsevu (resp. sklizně). Tato data by mohla být pro řadu regionů snadno součástí LPIS, nebot podniky plodiny vykazují (byt’ ne prímo ve vztahu ke konkrétnímu bloku) a obvykle si vedou přesnou evidenci. Bohužel pro výzkum nejsou taková data standardně dostupná, stále je tedy třeba se obracet na jednotlivé podniky a zajištovat osevní postupy individuálně.

Prostorová variabilita porostu je rovněž výborně evidována ve sklizňových mapách získaných prímo ze strojů pracujících $v$ režimu přesného zemědělství, nicméně tyto údaje se nevztahují k iniciálním fázím porostu, které je třeba zejména sledovat při výpočtech erozního rizika. Zde se do budoucna nabízí vyhodnocení prostorově variabilních dat aplikace hnojiv.

Testování dostupnosti bezoblačných scén pro zájmovou lokalitu za roky 2015-2017 ukázalo na stále vysoké riziko jejich nedostatečné dostupnosti v období nástupu přivalových srážek a rychlého rozvoje vegetačního pokryvu v rizikovém období červen-srpen. Zásadní pokrok nastal v roce 2017, kdy byla vypuštěna družice Sentinel $2 \mathrm{~B}$ a dosavadní problematická dostupnost dostatečného množství dat v ucelených časových řadách se výrazně zlepšila. Rovněž trojnásobné prostorové rozlišení a vylepšené spektrální rozlišení v oblasti red-edge umožňuje podstatně kvalitnější klasifikace vegetačních indexů.
Kombinaci družicových dat a informací o termínech agrotechnických zásahů Ize využít v protierozní ochraně a k optimalizaci pěstebních postupů s využitím precizního zemědělství, především se jedná o variabilitu použití nutrientů (prípadně herbicidů i pesticidů), nebo o zlepšení prostorové variability výsevu a trajektorií pojezdů na zemědělských pozemcích.

\section{Poděkování}

Autoři děkuji Ing. Vítězslavu Krčkovi, Ph.D., a podniku AGRA Řisuty, s. r. o., za poskytnutá data a dlouhodobou spolupráci prì terénnich kampaních a výzkumu erozních procesů. Článek byl připraven s podporou projektů EIP Implementace nových a inovovaných technologií precizního zemédělství do pěstebnich systémů, registrační čislo 16/003/1611a/120/000095 a QK1720289 Vývoj automatizovaného nástroje pro optimalizaci monitoringu eroze zemědělské půdy pomocí distančnich metod.

\section{Literatura}

[1] LUKAS, V., RYANT, P., NEUDERT, L., DRYŠLOVÁ, T., GNIP, P. a SMUTNÝ, V. Tvorba aplikačních map pro základni hnojeníplodin v precizním zemědělství. Brno: Mendelova univerzita v Brně, 2011.

[2] Sentinel 2 - Datové specifikace, 2018. [online]. [citováno: 15. června 2018]. Dostupné z: http://collgs. czechspaceportal.cz/sentinel-2-datove-specifikace/

[3] WISCHMEIER, W. and SMITH, D. Predicting rainfall erosion losses: a guide to conservation planning. U.S. Department of Agriculture Handbook, 1978, No. 537, p. 1-69.

[4] JANEČEK, M. Protection of agricultural land from erosion. Praha: ČZU, 2012.

[5] NOVOTNÝ, I. et al. Adjusting the CPmax factor in the Universal Soil Loss Equation (USLE): areas in need of soil erosion protection in the Czech Republic. Journal of Maps, 2016, vol. 12, No. sup1, p. 58-62.

[6] KRÁSA, J., DOSTÁL, T., VRÁNA, K., and PLOČEK, J. Predicting spatial patterns of sediment delivery and impacts of land-use scenarios on sediment transport in Czech catchments. Land Degradation \& Development, 2009, vol. 21, No. 4, p. 367-375

[7] DAVIDOVÁ, T., DOSTÁL, T., DAVID, V., and STRAUSS, P. Determining the protective effect of agricultural crops on the soil erosion process using a field rainfall simulator. Plant Soil Environ., 2015, vol. 61, No. 3, p. 109-115.

[8] ŽiŽ̌ALA, D., KRÁSA, J., BÁČOVÁ, M., ZELENKOVÁ, K., LABURDA, T. a NOVOTNÝ, I. Monitoring erozního poškozeni půd v ČR nástroji dálkového průzkumu Země. Praha: Výzkumný ústav meliorací a ochrany půdy, v. v. i., 2016

[9] “EarthExplorer-Home”, 2018. [online]. [citováno: 15. června 2018]. Dostupnéz: https://earthexplorer. usgs.gov/

[10] "GLCF: Data \&amp; Products", 2018. [online]. [citováno: 15. června 2018]. Dostupné: http://glcfapp. glcf.umd.edu/data/

[11] Sinergise, "Sentinel Hub", 2018. [online]. [citováno: 16. ledna 2019]. Dostupné z: https://www. sentinel-hub.com/

[12] “Land Viewer", 2018. [online]. [citováno: 15. června 2018]. Dostupné z: https://eos.com/landviewer/ [13] CUZK, "Digital Terrain Model of the Czech Republic of the 4th generation (DMR 4G)", 2018. [online]. [citováno: 20. dubna 2018]. Dostupné z: http://geoportal.cuzk.cz/(S(zdufzptexOtwvxiqwnanihxy)) /Default.aspx?Ing=EN\&mode=TextMeta\&side=vyskopis\&metadataID=CZ-CUZK-DMR4G -V\&head_tab=sekce-02-gp\&menu=301

[14] JANEČEK, M. a kol. Ochrana zemědělské pưdy pred erozí. Praha: ČZU, 2012.

[15] „Celostátní databáze BPEJ | Státní pozemkový úřad", 2019. [online]. [citováno: 17. ledna 2019] Dostupné z: https://www.spucr.cz/bpej/celostatni-databaze-bpej

[16] MISTR, M. a kol. Stanovení faktoru ochranného vlivu vegetace pomocí simulátoru deště. Praha: Výzkumný ústav meliorací a ochrany půdy, v. v. i., 2016.

[17] MITASOVA, H., MITAS, L., BROWN, W.M., and JOHNSTON, D. Multidimensional soil erosion/deposition modelling. Part III: Process based erosion simulation. Urbana: University of Illinois at Urbana-Champaign, 1996.

[18] DESMET, P.J.J. and GOVERS, G. A GIS procedure for automatically calculating the USLE LS factor on topographically complex landscape units. Journal of Soil and Water Conservation, 1996, vol. 51, No. September 1996, p. 427-433.

[19] NEARING, M.A. A single, continuous function for slope steepness influence on soil loss. SSSAJ, 1997, vol. 61, No. 3, p. 917-919. 


\section{Autoři}

doc. Ing. Josef Krása, Ph.D.

凶josef.krasa@fsv.cvut.cz

Ing. Adam TejkI

凶adam.tejkl@fsv.cvut.cz

Ing. Jakub Stašek

凶jakub.stasek@fsv.cvut.cz

Katedra hydromeliorací a krajinného inženýrství, Fakulta stavební,

ČVUT v Praze

Příspěvek prošel lektorským řízením.

\section{DETERMINATION OF THE EXTENT \\ OF SOIL UNPROTECTED BY VEG- \\ ETATION IN THE PERIOD OF RAIN- STORMS TO ASSESS EROSION RISK}

\section{KRASA, J.; TEJKL, A.; STASEK, J.}

Department of Landscape Water Conservation, Faculty of Civil Engineering, CTU in Prague

Keywords: soil erosion by water - GIS remote sensing - precision agriculture

The article describes the method, the source data, and the results of analyses of bare soil by remote sensing and its relation to soil erosion risk. The method was tested on the parcels of AGRA Řisuty, s. r. o. Data from the satellites Landsat 8 and Sentinel 2 were used for detecting the presence of vegetation cover on each parcel. Furthermore, existing data of seeding and harvest are used for creating training polygons and for calculation of the protective effect of vegetation. Satellite scenes retrieved from the server "Land Viewer" were processed in a GIS. Maximum likelihood supervised classification was performed.

Plots with a total area exceeding 1500 ha were monitored for three growing seasons (2015-2017). The riskiest was the year 2015 when the bare soil occurred up to 1.000 ha during the period of July and August. An important factor for the occurrence of bare soil in the period of the occurrence erosive rainfalls was sowing winter oilseed rape.

The rigors of the approach are the low availability of the cloudless satellite scenes for period of torrential rainfall, and rapid development of the growing cover in the period June-August. The method seems suitable for use by individual agricultural businesses, when uncertainty in determining the soil cover is further reduced by easy availability of calibration data from the field, and easy access to the crop data. The launch of the satellite Sentinel 2 B in the year 2017 also improved the availability of a sufficient amount of data in a consistent time series. 